\title{
JUSTIFICAÇÃO E EXPERIÊNCIA NA TRAJETÓRIA DOS ATINGIDOS PELA BARRAGEM DE JAGUARA - SP
}

\author{
Jéssica Pires Cardoso ${ }^{1}$ \\ https://orcid.org/0000-0002-0180-1737 \\ Rodrigo Constante Martins ${ }^{2}$ \\ https://orcid.org/0000-0003-2700-3319
}

\section{RESUMO}

A Usina Hidrelétrica de Jaguara, construída na década de 1960, no interior do estado de São Paulo, deslocou compulsoriamente um grande número de famílias agricultoras e não agriculturas durante formação do lago artificial. $\mathrm{O}$ artigo em tela tem como objetivo problematizar os posicionamentos divergentes e controversos entre os atingidos pela construção da barragem, bem como as diferentes estratégias de atuação desse grupo social junto à concessionária responsável pela obra, seja para minimizar perdas, ou para oportunizar ganhos no campo particular e pessoal. Para a realização do estudo, foram utilizados procedimentos qualitativos de pesquisa social, dentre os quais entrevistas semiestruturadas e coleta de relatos orais. Também foi utilizado um amplo levantamento documental do período de construção e início das atividades da UHE. Na análise dos resultados, foram problematizados os temas relacionados à reestruturação territorial, social e simbólica dos atingidos; e aos conflitos entre os grupos sociais, a depender das experiências (amparado na sociologia de E.P. Thompson) e das justificações (amparado na sociologia de Luc Boltanski). Como resultado, entendese que não há um consenso entre os atingidos a respeito dos impactos da construção da barragem, mas uma multiplicidade de experiências e diferentes significações que transitam entre as ameaças de perdas e as oportunidades de ganhos.

Palavras-chave: Ruralidades e Meio Ambiente, Ciências Sociais e Barragens, Sociedade e Recursos Hídricos.

\section{JUSTIFICATION AND EXPERIENCE FROM THE PEOPLE AFFECTED BY THE JAGUARA WATER DAM - SP}

\begin{abstract}
The Jaguara Hydroelectric Station, built in the 1960s at the countryside of São Paulo state, compulsorily moved many farming and non-farming families when its artificial lake was formed. This article aims to discuss the diverging and controversial positions among those people affected by the dam construction, as well as outline different strategic actions taken by this social group alongside with the concessionaire responsible for the dam's construction, either minimizing losses or allowing personal and private gains. For the study, methods employed concerned qualitative social research procedures, including semi-structured interviews and oral reports. We also conducted an extensive documentary research on the construction period of the dam and during its initial activities. Data analyses considered problematizing topics related to territorial, social and symbolic restructuration among the people affected; as well topics related to conflicts between the social groups, depending on their experiences (supported by the sociology of E.P. Thompson) and their justifications (supported by the sociology of Luc Boltanski). As a result, we understand that there is no consensus

\footnotetext{
${ }^{1}$ Mestra em Sociologia pela Universidade Federal de São Carlos (UFSCar). Doutoranda no Programa de Pós-Graduação em Sociologia da UFSCar. E-mail: jessicapires.cardoso@gmail.com.

${ }^{2}$ Doutor pela Universidade de São Paulo, com pós doutorado pela École des Hautes Études en Sciences Sociales de Paris. Professor do Departamento de Sociologia e do Programa de Pós-Graduação em Sociologia da UFSCar. E-mail: rmartins@ufscar.br.
} 
among the people affected regarding the impacts of the dam construction, but a multiplicity of experiences and diverse significations that shift from threats of losses to gain opportunities.

Keywords: Rurality and Environment, Social Sciences and Dams, Society and Water Resources.

\section{JUSTIFICACIÓN Y EXPERIENCIA EN LA TRAYECTORIA DE LOS AFECTADOS POR LA REPRESA JAGUARA - SP}

\section{RESUMEN}

La central hidroeléctrica de Jaguara, construida en la década de 1960 al interior del estado de São Paulo, generó el desplazamiento de un gran número de familias agricultoras y no agricultoras durante la construcción del embalse. El presente artículo tiene como objetivo problematizar los posicionamientos divergentes y controversiales entre los afectados por la construcción de la represa, así como las estrategias de actuación de este grupo social frente a la empresa responsable de la obra, tanto para minimizar las pérdidas como para potencializar las ganancias en el plano particular y personal. Para la realización del estudio se utilizaron técnicas cualitativas de investigación social como entrevistas semiestructuradas y relatos orales. También se llevó a cabo una amplia revisión documental del periodo de construcción e inicio de las actividades de la hidroeléctrica. En el análisis de los resultados fueron problematizados los temas referentes a la reestructuración territorial, social y simbólica de los afectados; y, a los conflictos entre los grupos sociales dependiendo de las experiencias (amparados en la sociología de E.P. Thompson) y de las justificaciones (amparado en la sociología de Luc Boltanski). Como resultado, se entiende que no hay un consenso entre los afectados en relación a los impactos de la construcción de la represa, sino una multiplicidad de experiencias y diferentes significaciones que transitan entre las amenazadas de pérdidas y las oportunidades de ganancias.

Palabras-clave: Entorno Rural y Medio Ambiente, Ciencias Sociales y Represas, Sociedad y Recursos Hídricos.

\section{INTRODUÇÃO}

Ao longo das últimas décadas, a retomada das construções de barragens para a geração de energia hidrelétrica ampliou significativamente o campo de discussão, compreensão e reflexão da temática (Henriques, 2015). Considerado um objeto de pesquisa privilegiado (Locatelli, 2015), a temática possui diversas complexidades, dentre as quais destacamos a interdependência de vários atores sociais que disputam interesses distintos e instituem zonas de tensão a partir de relações de poder. De fato, uma ampla rede de agentes entra em jogo, concorre politicamente, tensiona interesses e disputa a legitimidade no momento em que se instala o empreendimento. Nessa perspectiva, as disputas e tensões não se fixam em um conflito binário entre o órgão propositor da obra e aqueles que ocupam o território alagado, mas perfaz uma complexa rede de agentes sociais que compõe o espaço físico e o espaço social.

Ainda nesse enquadramento, compreendemos que as percepções e as experiências daqueles que vivenciam a construção de uma barragem e o deslocamento compulsório não são unívocas, atingindo um corolário real e singular. Ao contrário, partimos do pressuposto de que, mesmo entre os 
oficialmente considerados atingidos ${ }^{3}$, há posicionamentos divergentes e disputas diversas que refletem confrontos de interesses e percepções opostas sobre os impactos das barragens. E é sobre esse aspecto que o artigo se debruça: a experiência dos atingidos pela construção da barragem. Mais especificamente, interpretaremos o fracionamento das percepções dos atingidos no que tange aos impactos sociais da formação do lago artificial, bem como as justificações para tal. Pretendemos, ainda, analisar as diferentes estratégias de atuação desse grupo social junto à concessionária responsável pela obra.

Para tanto, apresentaremos um estudo de caso realizado no município de Rifaina, situado na região nordeste paulista. O município, banhado pelo Rio Grande, pertence à área de influência do reservatório hídrico da Usina Hidrelétrica (UHE) de Jaguara, empreendimento que submergiu tanto o território urbano quanto o rural no auge da ditadura militar. Além desta razão, a escolha do município também se deve à memória dos citadinos atingidos pela construção da barragem, reacendida pela metodologia qualitativa a partir da técnica de história oral, e as transformações de uso do território após a formação do lago artificial. A este respeito, a cidade passou a ser identificada pela população regional como um local privilegiado para o lazer e recreação, e não mais como um espaço de produção agrícola, produção de cerâmicas e de olarias familiares.

Para fins de exposição, o artigo em tela está estruturado em seis seções. Após esta breve introdução, serão apresentados os procedimentos metodológicos utilizados no estudo de caso. $\mathrm{Na}$ terceira seção, reconstruímos analiticamente o espaço social do lago artificial de Jaguara, apresentando as principais mudanças econômicas locais e as transformações nas sociabilidades com a submersão de terras produtivas. Na quarta seção, expomos a rede de famílias atingidas pela barragem e nos debruçamos sobre os argumentos controversos e divergentes acerca dos impactos da UHE de Jaguara, lançando mão da noção de justificação (Boltanski; Chiapello, 2009) para apresentar a pluralidade dos discursos. Na quinta seção, versamos sobre as variadas estratégias de atuação das famílias atingidas, seja para minimizar as perdas, ou para oportunizar ganhos pessoais junto à concessionária propositora da obra. Por fim, finalizamos o texto com as considerações finais, em que retomamos os argumentos centrais.

\footnotetext{
${ }^{3}$ A noção de atingido utilizada na realização deste estudo tem como base as reflexões de Vainer (2008), segundo o qual identifica a expressão "atingido" como uma noção em constante disputa, que varia no tempo e no espaço consoante ao contexto político e cultural da época, e tem em seu cerne o reconhecimento do direito a algum tipo de ressarcimento e compensação, reparação e indenização a perdas de objetos materiais e imateriais.
} 


\section{PROCEDIMENTOS METODOLÓGICOS}

Em termos metodológicos, optamos pela metodologia da história oral, visto que ela possibilita aprofundar no estudo de caso; proporciona o acesso a fatos históricos que não estão registrados em outras fontes documentais; e privilegia as falas dos agentes sociais tornando audível o até então “inaudível”, dizível o até então “indizível”. Dentre os vários procedimentos que são apontados por Queiroz (1991), optamos pela coleta de depoimentos pessoais (Queiroz, 1991) a partir de entrevista qualitativa semiestruturada, com a confecção do tópico guia (Gaskell, 2003).

Dentre outros aspectos, a escolha dessa metodologia possibilita entrar em contato com a experiência humana, noção que tem como base as proposições de Thompson (1981, p. 182), segundo o qual os indivíduos “experimentam suas situações e relações produtivas determinadas como necessidades e interesses como antagonismos, e em seguida 'tratam' essa experiência em sua consciência e sua cultura das mais complexas maneiras e em seguida agem, por sua vez, sobre sua situação determinada.”

A escolha das famílias entrevistadas foi balizada por três orientações, "uma decorrente do tema em pauta, a outra decorrente de se saber que determinado indivíduo possui conhecimentos importantes a respeito do tema" (Queiroz, 1991, p. 06), e ainda a experiência de vivenciar um contexto social e histórico específico. De modo geral, as entrevistas foram conduzidas com o objetivo de compreender a trajetória social das famílias que residiam no local inundado, isto é, a partir do deslocamento compulsório, compreender os impactos sociais desse momento histórico e, a posteriori, a necessária reestruturação da vida. Dessa forma, a relação dos agentes com a terra e com o território antigamente habitado foi elemento primordial para o balizamento das entrevistas, visto que, a partir daí, compreendemos as diferentes percepções acerca dos impactos pessoais decorrentes da formação do lago artificial.

Com relação à análise documental, coletamos matérias jornalísticas do acervo digital dos jornais "O Estado de São Paulo" e "O Globo" sobre a construção de Jaguara. Delimitamos como intervalo de análise as décadas de 1950 a 19704. Além disso, foram analisadas algumas escrituras de desapropriação amigável no período da formação da UHE de Jaguara, levantadas no Cartório de Registo de Imóveis e Anexos de Pedregulho/SP 5 . Por fim, após esta fase, foi possível encontrar processos judiciais arquivados no Fórum da Comarca de Pedregulho, de conflitos pela terra depois do reordenamento territorial do município de Rifaina, por volta da década de 1980.

\footnotetext{
${ }^{4}$ Foram encontradas 14 reportagens no jornal "O Globo" e 33 reportagens no jornal "Folha de São Paulo".

${ }^{5}$ Os registros de desapropriações de imóveis feitos pela CEMIG, ainda que tramitadas em Rifaina, foram transferidas e arquivadas no município de Pedregulho - SP, 27 km de distância.
} 


\section{O MUNICÍPIO DE RIFAINA E O LAGO ARTIFICIAL DE JAGUARA}

O município de Rifaina, fundado oficialmente em 1948, após um intenso processo de doações de terras e pela influência direta da construção da Estrada de Ferro Mogiana, conta atualmente com uma população em torno de 4 mil habitantes. Localizado na região nordeste do Estado de São Paulo, o município integra a área de influência da UHE de Jaguara, construída no auge da ditadura militar. Em 1971, iniciou-se a formação gradativa do lago artificial de Jaguara, processo que, além de deixar submerso grande extensão da zona rural e parte importante da área urbana de Rifaina, deslocou compulsoriamente famílias inteiras da região (Zanfelice; Etchebehere; Saad, 2009).

No curso dos últimos quarenta anos, os reflexos da construção da barragem são perceptíveis econômico e socialmente. De modo mais específico, as lavouras de arroz e as olarias de cerâmicas administradas pelas famílias citadinas foram gradativamente substituídas pelo turismo rural, principal atividade econômica da região de Rifaina atualmente. Como demonstrou Cardoso (2016), essa transformação ocorreu pela confluência de fatores essenciais, dentre os quais elencamos, no momento, a) a inundação de terras férteis e produtivas durante a formação do lago artificial, restando locais impróprios para a plantação e colheita dos arrozais, ou mesmo para a retirada de barro das margens do rio Grande; e b) a ressignificação do espaço rural, que deixou de ser compreendido como local essencialmente produtivo e passou a ser valorizado pelas dimensões simbólicas, tornando-se espaço de consumo, sobretudo pelas dimensões de lazer e de residência ${ }^{6}$.

A confluência dos fatores citados anteriormente transformou sobremaneira a rotina de vida e a sociabilidade de um local que, até então, tinha uma organização tipicamente caipira (Candido, 2010). A partir das informações colhidas na pesquisa de campo, é possível inferir que, do ponto de vista simbólico, até a construção da UHE de Jaguara, uma importante parcela da população rifainense estabelecia estreita relação com a agricultura de subsistência, tendo a terra como base produtiva. A organização de trabalho e geração de renda fundamentada na produção agrícola estava orientada para a função social de mantê-los conectados com a natureza e estabelecer reciprocidades. Do ponto de vista econômico e de subsistência, a organização de trabalho das famílias era conduzida pelos ritmos das águas do Rio Grande, das estações - época das chuvas e da seca -, além da coleta, caça e pesca. Assim, tais atividades, longe de significar uma atividade em si e para fins econômicos, concatenam sabedorias e múltiplas racionalidades ligadas ao projeto de vida de equilíbrio vital entre o agente e a natureza.

\footnotetext{
${ }^{6}$ Notadamente, esta ressignificação do rural como espaço de lazer associado aos atrativos ambientais não é uma particularidade de Rifaina. Outros territórios rurais do estado de São Paulo se voltaram a esta modalidade de turismo. Exemplo importante a este respeito, também associado ao atrativo dos recursos hídricos, é o município de Brotas. A este respeito, ver Martins e Madureira (2019).
} 
Dito isso, as famílias atingidas reproduziam mecanismos ou estratégias de ação na produção agrícola que combinavam subjetividade e racionalidade (Brandenburg, 2010). Uma racionalidade que lhe é própria na medida em que nega os ideais do cálculo como garantia da equidade da troca, ou seja, nega a ação orientada pelo "cálculo interessado, as da concorrência, as da competição ou as da exploração" (Bourdieu, 1979, p. 41). Ademais, essa racionalidade combinava sabedoria e clareza sobre o ciclo de produção da planta e sobre a dança das águas do rio, proporcionando aos donos de terra, arrendatários, parceiros e meeiros a possibilidade de planejarem a geração da renda familiar.

Durante o ano, os períodos opostos entre tempo das "secas" e tempo das "águas" guiavam a alternância do trabalho e a produção rural. Seis meses bem demarcados que orientavam a vida e a economia das famílias da região apoiado na plantação da roça nos tempos das "águas”, com o início do plantio no mês de novembro e colheita em janeiro/fevereiro, e as olarias e cerâmicas nos tempos das "secas", de março a outubro. Comumente, todos os membros das famílias eram envolvidos nas atividades agrícolas da unidade. Contudo, nas olarias e cerâmicas, mulheres e homens não exerciam a mesma tarefa. Na divisão sexual do trabalho, coube ao homem o trabalho "pesado", em atividades que requerem maior força física, como ir às olarias, retirar o barro, carregar tijolos. À mulher, competia as atividades no âmbito doméstico, ligadas à organização da casa e de cunho "leve". No que tange às atividades agrícolas, mesmo que ambos participassem ativamente das mesmas etapas de plantio e colheita, como era de costume, as atividades das mulheres eram categorizadas como trabalho "leve", traduzidas muitas vezes como "ajuda" ao pai/marido.

Nesse cenário, expressões como "a plantação dava para o gasto", "éramos sortudos”, "terras abençoadas", "terra sagrada", "respeitar o tempo da produção", "fazíamos mutirão", "a terra era fértil", dentre outras, foram frequentes no universo da memória dos atingidos. Foi notório também o respeito aos ritmos e mistérios da sucessão temporal da produção agrícola, determinando uma relação de "reciprocidade de troca de dádivas", e ainda uma valorização simbólica da terra seja entendida como espaço de moradia ou como local de produção.

Em contrapartida, outro segmento da atividade econômica da cidade afastava-se da dimensão agrícola, rompia com o universo que Candido (2010) nomeou de civilização caipira e, nos casos em que a terra era um elemento particular da produção familiar, havia um distanciamento entre o ser social e a natureza a partir do trabalho, orientado como uma atividade em si e para fins econômicos (Weber, 1991). Ou seja, uma parcela das famílias da cidade elaborou de maneira bem própria as combinações econômicas para o sustento familiar, afastando-se da reprodução social na agricultura.

Concretamente, a organização de trabalho fundamentada na roça, nas olarias e nas cerâmicas não era vista como uma atividade próspera e rentável. Ao contrário, tanto o espaço rural quanto o modo de vida caipira carregavam intrinsecamente características pejorativas e estereótipos negativos como atrasado, grosseiro e arcaico, e as categorias urbanas e os valores concebidos típicos da cidade 
eram valorizados e estimados. Exatamente por isso, muitos buscavam a inserção no mercado formal, emprego em áreas não agrícolas, ou ainda, quando havia a proximidade com a produção agrícola, reproduziam os padrões capitalista de produção e acumulação monetária.

Posto isso, trata-se de outro ajustamento da vida social do camponês que rompe com a vida econômica e social centrada na vida comunitária rural e integra-se ao mercado reorientando os sistemas produtivos (Brandenburg, 2010).

A integração às sociabilidades do meio urbano e do mercado se cristalizou antes mesmo da construção da UHE de Jaguara. Mais especificamente, em dois momentos. Primeiro, quando algumas famílias optaram pela segurança de uma renda fixa mensal assentada no aluguel de residências, afastando-se das leis naturais que regem tanto a produção agrícola quanto a feitura de tijolos e cerâmicas. Segundo, quando os pais, em clara estratégia de mobilidade social, estimularam o estudo e o emprego formal das filhas e dos filhos (Cardoso, 2016). Vemos, dessa forma, um dos efeitos do processo de desvalorização da cultura camponesa que, em diferentes contextos sociais, pode resultar na permanência ou não de jovens na atividade agrícola, ou ainda, na elaboração de estratégias para sair do espaço rural e migrar para a cidade (Bourdieu, 2002; Stropasolas, 2004).

No que se refere às relações de gênero, apesar de um olhar preocupado com o estudo e a estabilidade das filhas e dos filhos, a atenção dada às mulheres seguiu lógicas contrárias. Ou seja, persistiu a dominação de gênero e a divisão sexual das atividades em que coube ao homem a responsabilidade do trabalho produtivo e acesso aos estudos, e à mulher, o trabalho reprodutivo relativo aos cuidados domésticos e de care $^{7}$.

Desde a aprovação da construção da usina hidrelétrica de Jaguara, no Médio Rio Grande, até a efetiva formação do lago artificial, no ano de 1971, as reconfigurações espaciais e econômicas da região e as transformações sociais e simbólicas das famílias foram intensas. A submersão de terras férteis e áreas de produção agrícola, expropriando os instrumentos de trabalho de várias famílias, obrigou os trabalhadores a migrar à procura de um novo território para reconstruir os laços sociais rompidos, estabelecendo, assim, novas relações de trabalho, novas práticas de vida e novas maneiras de uso e ocupação do solo. Do ponto de vista simbólico, o deslocamento compulsório desestrutura um modo de vida bem próprio do meio rural, caracterizado pelos laços de pertencimento a uma comunidade, pelo respeito aos ritmos da produção agrícola e pela interdependência entre os agentes sociais.

\footnotetext{
${ }^{7}$ De acordo com Hirata e Guimarães (2012, p. 01), o termo care "é dificilmente traduzível porque polissêmico. Cuidar do outro, preocupar-se, estar atento às suas necessidades, todos esses diferentes significados, relacionados tanto à atitude quanto à ação, estão presentes na definição do care".
} 
Mapa 1 - Mapa das regiões administrativas do Estado de São Paulo

(Destaque para o município de Rifaina)

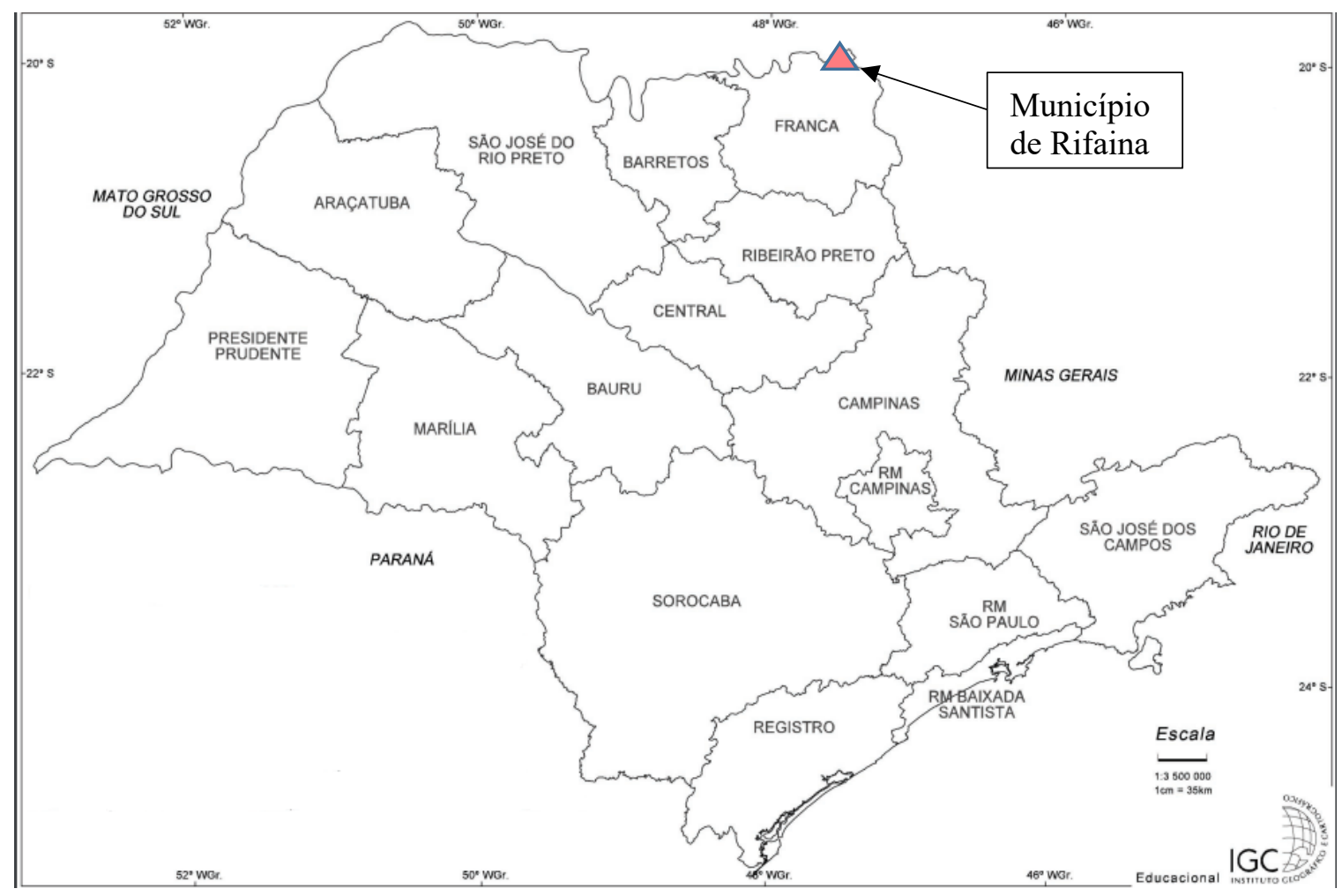

Fonte: Instituto Geográfico e Cartográfico. Adaptado pelos autores.

Figura 2: Imagem de satélite localizando UHE de Jaguara

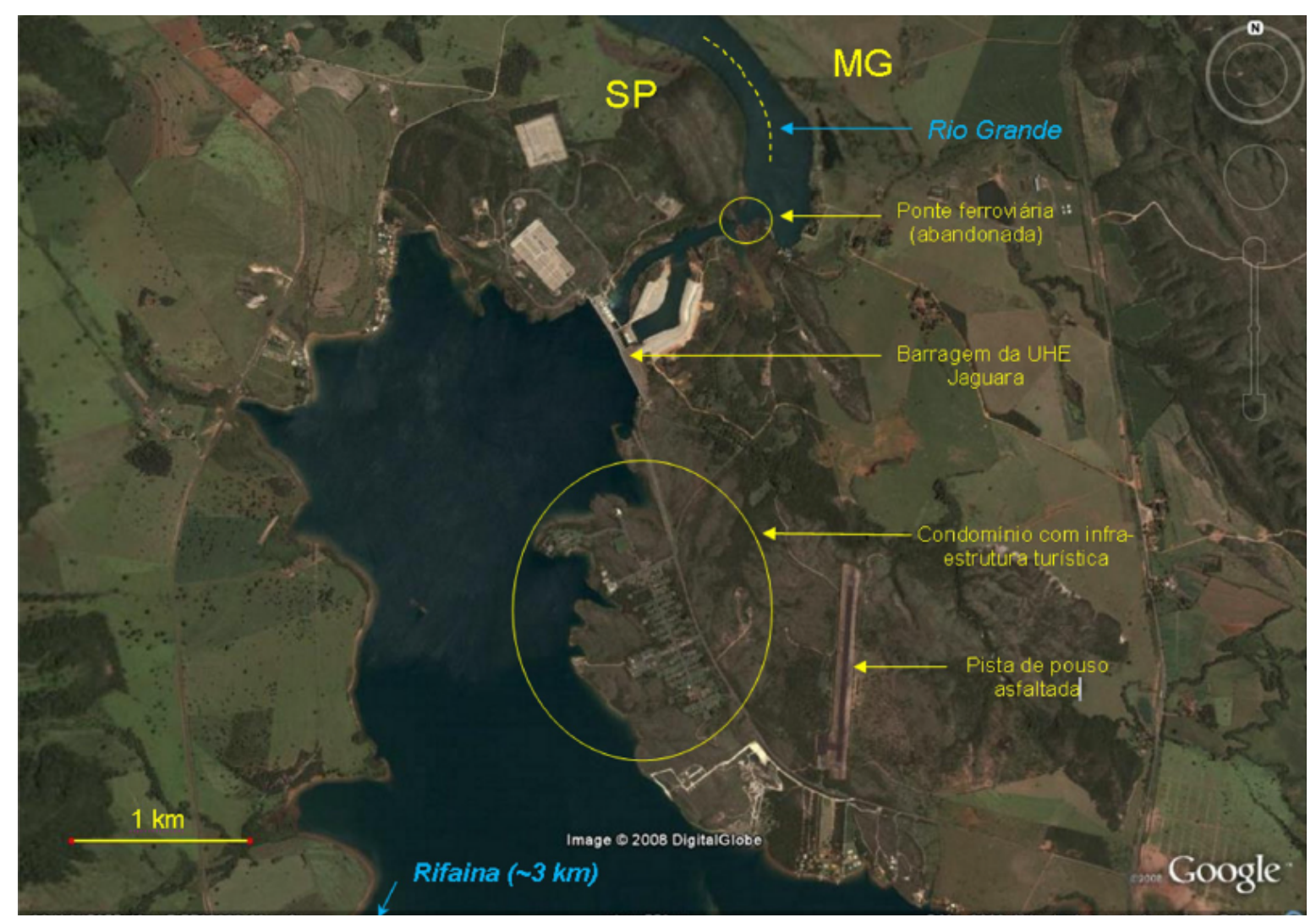

Fonte: Zanfelice et al (2009). 
Em contrapartida, a formação do lago artificial, em conjunto com a ressignificação do rural, incitou o surgimento de uma nova modalidade econômica na região: o turismo rural. A construção de ranchos e casas de veraneio de alto padrão nas margens do rio Grande deu um novo dinamismo econômico para a região. Com as mudanças nos modos de apropriação, uso e ocupação da terra, o rural deixa de ser valorizado por sua capacidade produtiva agrícola, e ainda, afasta de seu bojo as categorias pejorativas e a noção de atraso que o circundava. Por sua vez, o espaço rural passa a ser oferta de consumo às classes médias urbanas que, com o objetivo de se afastarem do ritmo agitado e dos "males" da cidade, se aproximam do rural em busca de tranquilidade e segurança, por exemplo. As águas límpidas do lago artificial passam a ser (e devem ser) preservadas em um contexto de intenso desgaste dos recursos naturais, e o processo de ressignificação do rural e emergência do debate ambiental ampliam essa visão.

Dito isso, aqueles que se afastavam de uma base agrícola para o sustento familiar, e que permaneceram na cidade, aproveitaram as novas estruturas territoriais, os novos atores sociais que passaram a frequentar o município e as novas relações mercadológicas para aprimorar os negócios particulares e aumentar o rendimento monetário.

Logo, o município de Rifaina, afetado pela construção da UHE de Jaguara e desprovido, até então, de atividades econômicas com razoável dinamismo, vivenciou a abrupta submersão de uma atividade econômica familiar baseada na agricultura e, paralelamente, a reconversão econômica no âmbito daquela localidade. O turismo passou a guiar a economia regional, tornando-se um meio fecundo de retorno financeiro para as famílias citadinas. Por conseguinte, o território foi cercado dos que vinham "de fora", reforçando as transformações nas relações sociais estabelecidas até então e despertando conflitos de diversas ordens entre os "de dentro" e os "de fora".

Esta tessitura, contudo, não pode ser compreendida senão através da presença marcante deste grande empreendimento em confluência com as dimensões simbólicas, as relações com a terra e a organização de trabalho que envolvem os atingidos, antes mesmo da chegada da UHE. Adquire, desta feita, grande importância analítica, uma vez que abre caminhos para problematizar as percepções dos impactos da construção da barragem a partir das experiências individuais e da relação sociedadenatureza. Tomando como base esse cenário múltiplo de relações sociais, econômicas e simbólicas que circundam o território, o processo de construção de barragem adquire um significado multifacetado a cada atingido. Significados e experiências que se afastam de um pensamento dicotômico que supõe, automaticamente, um compilado de perdas irreversíveis e irreparáveis àqueles que vivenciam o deslocamento pós construção da barragem.

Para não cair em tal equívoco analítico, a investigação adquire um conteúdo histórico que ultrapassa o período de edificação da barragem, e abrange as experiências e os modos de vida dos atingidos antes e após a construção da UHE, momento de reordenamento territorial e social. Ademais, 
tomamos, como elemento de distinção entre os indivíduos, o território, não como simples espaço físico, mas espaço social de disputas, hierarquias e contradições que situa e posiciona os agentes sociais em lugares distintos. Estas estratégias, em grande medida, viabilizam que os posicionamentos divergentes e controversos dos atingidos entrem em cena e possibilitam compreender o modo como as pessoas justificam as suas práticas e o sentido subjetivo que atribuem às suas ações.

A seguir, analisaremos mais detidamente os múltiplos argumentos dos atingidos no que tange aos impactos da construção da UHE de Jaguara. Argumentos que não compreendem uma percepção unívoca sobre os impactos, mas um emaranhado de experiências divergentes, com motivações e justificações próprias. Partiremos dos relatos orais dos mesmos para interpretar como a chegada de um grande empreendimento hídrico, inundação do território e deslocamento compulsório é percebido de múltiplas formas, a depender, principalmente, da relação com a terra e do modo como organizaram o trabalho, produção e geração de renda.

\section{PERDAS E GANHOS NA CONSTRUÇÃO DA UHE DE JAGUARA}

Tendo em vista o contexto de uso e ocupação da cidade de Rifaina, bem como as transformações espaciais, econômicas e sociais pós formação do lago artificial de Jaguara, as percepções sobre os impactos da barragem e as experiências dos atingidos foram diversas. A fim de mostrar estas experiências, apresentaremos os resultados das entrevistas qualitativas realizadas com cinco famílias atingidas, os quais serão apontados no quadro 1.

De modo geral, não existe um consenso entre os atingidos a respeito dos impactos da construção da UHE de Jaguara. O que existe é uma multiplicidade de experiências e diferentes significações acerca da inundação do território, do deslocamento compulsório e das "perdas" materiais, monetárias e simbólicas envoltas nesse processo. Há, sobretudo, disputas e hierarquias de grupos divergentes que enxergam tanto ameaças de perdas quando da construção da UHE de Jaguara, como também oportunidades de ganhos.

QUADRO 1: Caracterização dos informantes das famílias atingidas pela UHE de Jaguara

\begin{tabular}{|c|c|c|c|c|c|c|c|}
\hline FAMÍLIA* & $\begin{array}{c}\text { Sexo e } \\
\text { idade } \\
\text { (Ano 2015) }\end{array}$ & $\begin{array}{c}\text { Condição de } \\
\text { trabalho até } \\
1971\end{array}$ & $\begin{array}{c}\text { Condição de } \\
\text { trabalho pós } \\
1971\end{array}$ & $\begin{array}{c}\text { Residência } \\
\text { até 1971 }\end{array}$ & $\begin{array}{c}\text { Residência } \\
\text { pós 1971 }\end{array}$ & $\begin{array}{c}\text { Relação com a } \\
\text { terra até 1971 }\end{array}$ & $\begin{array}{c}\text { Relação com } \\
\text { a terra pós } \\
1971\end{array}$ \\
\hline $\begin{array}{c}\text { Família de } \\
\text { Alcides }\end{array}$ & $\begin{array}{c}\text { Masculino } \\
88 \text { anos }\end{array}$ & Camponês & $\begin{array}{c}\text { Trabalhador } \\
\text { rural }\end{array}$ & Rural & Urbano & Proprietário & Proprietário \\
\hline $\begin{array}{c}\text { Família de } \\
\text { Berenice }\end{array}$ & $\begin{array}{c}\text { Feminino } \\
67 \text { anos }\end{array}$ & Camponesa & $\begin{array}{c}\text { Trabalhadora } \\
\text { rural }\end{array}$ & Rural & Urbano & Proprietária & Proprietária \\
\hline $\begin{array}{c}\text { Família de } \\
\text { Carlos }\end{array}$ & $\begin{array}{c}\text { Masculino } \\
87 \text { anos }\end{array}$ & Camponês & Assalariado & Rural & Urbano & Parceiro & Proprietário \\
\hline
\end{tabular}




\begin{tabular}{|c|c|c|c|c|c|c|c|}
\hline $\begin{array}{c}\text { Família de } \\
\text { José Pedro }\end{array}$ & $\begin{array}{c}\text { Masculino } \\
69 \text { anos }\end{array}$ & $\begin{array}{c}\text { Trabalhador } \\
\text { rural }\end{array}$ & Assalariado & Rural & Urbano & Proprietário & Proprietário \\
\hline $\begin{array}{c}\text { Família de } \\
\text { Antônio } \\
\text { Maria }\end{array}$ & $\begin{array}{c}\text { Masculino } \\
70 \text { anos }\end{array}$ & $\begin{array}{c}\text { Trabalhador } \\
\text { rural }\end{array}$ & Assalariado & Rural & Urbano & Proprietário & Proprietário \\
\hline
\end{tabular}

Fonte: Informações obtidas nas entrevistas qualitativas realizadas entre os meses de junho e dezembro de 2015.

*Todos os nomes das famílias entrevistadas são fictícios.

As famílias de Alcides, Berenice e Carlos, antes da construção da UHE de Jaguara, caracterizavam-se pelo que nomeamos anteriormente de uma civilização caipira. Essa categorização pode ser vista não apenas pelo modo como organizaram o trabalho, produção e geração de renda, fundamentado na produção agrícola, mas pelo vínculo de confiança entre os familiares e a vizinhança, sentimento de solidariedade, auxílio mútuo e intensa relação de troca entre os moradores. Ademais, a ligação dessas famílias com a terra extrapolava a relação de trabalho. Estabelecia-se também laços de afetividade, sentimento de pertencimento a um lugar carregado de significados que dizia respeito ao passado, presente e futuro. Local particularmente valorizado por estar ligado a uma lembrança e uma memória, no qual os indivíduos vão se (re)encontrar com o legado cultural que se perpetua por experiências passadas (Halbwachs, 2006).

De maneira oposta, as famílias de José Pedro e de Antônio Maria podem ser caracterizadas pelos valores que Brandenburg (2010) nomeou de "rural moderno". Nessa perspectiva, há a redefinição das condições da vida camponesa, não mais tipificadas pelas condições de vida do camponês tradicional, mas pela modernização e reorganização das sociabilidades a partir da proximidade à sociedade global. Essa integração ao meio urbano foi gradual e se concretizou por duas vias: i) o estímulo ao estudo e ao emprego formal dos integrantes da segunda geração, como reconstruído na fala a seguir.

Eu estudei na escola de Rifaina. Fui para a admissão e fui estudar em Franca, no Colégio Champagnat, de 1955 a 1960. Em 1960, eu saí, estudei no Instituto Francano de Ensino. Fiz contabilidade de 1961 a 1963 . Voltei para Rifaina e fiquei até 1967. Fui morar com a Leila (irmã) em Pedregulho, até 1969, e também fiz o curso normal. Em 1970, entrei para faculdade de Letras, em Passos, fiz até 1973 e, em 1976, fui pra Ribeirão fazer especialização. Mas sempre dando aula. Comecei a dar aula no segundo ano da faculdade. Naquele tempo não tinha tanta faculdade, e os professores eram procurados que nem diamante (Família Antônio Maria, entrevista realizada dia 14/07/2015).

E, ainda, ii) por meio da reorientação da organização de trabalho, produção e geração de renda. A integração às sociabilidades do meio urbano e ao mercado instaurou mudanças nos processos técnicos de produção, suprimindo as dimensões de submissão e encanto com a natureza que estreitavam os laços de solidariedade entre os trabalhadores e o meio natural.

Ele [pai] era um homem empreendedor. Ele tinha várias frentes de negócio, certo? Ele mexia com tijolos, mexia com lenha, mexia com pedra. Sim, ele explorava uma pedreira! E mexia com fazenda, certo? Então ele era assim. Tinha uma visão bem ampla mesmo. Além disso 
tudo, construiu várias casas de aluguel na cidade. Era um verdadeiro empreendedor (Família Antônio Maria, entrevista realizada dia 14/07/2015. Grifo dos autores)

Tomando Weber como referência para interpretar a racionalidade da conduta individual, observamos na família de Antônio Maria uma ação racional com referência ao objetivo de acumulação monetária. Dessa forma, os apontamentos acima salientam uma ação em que o agente concebe claramente seus objetivos, mobilizando os meios disponíveis para alcançá-lo, seja recorrendo aos recursos naturais ou seja construindo casas na cidade para obter uma renda fixa mensal no mercado imobiliário de locação. Fica evidente a busca pela garantia da geração de renda, lucro e aumento dos bens familiares com base em uma ação racional orientada para fins econômicos. A família de José Pedro segue os mesmos propósitos de se aproximar de uma ocupação mais atraente monetária e simbolicamente, com referência à busca por "algo certo". De tal sorte que há uma tentativa da família de superar as possíveis limitações inerentes à agricultura para o acúmulo do capital por meio do distanciamento da dependência com a terra.

Meu pai trabalhou em lavoura e chegou a trabalhar em olarias também. Porque na época que
não era de plantação ele ia para a olaria. Mas quando a linha de ferro Mogiana chegou -
porque aqui tinha linha de ferro, né? - ele foi para lá trabalhar. Lá era algo certo. E ficou lá
até inundar a região (Família José Pedro, entrevista realizada dia 17/07/2015. Grifo dos
autores).

Vemos aqui um novo elemento que intensifica o distanciamento da família de José Pedro com a terra e sua aproximação com os novos fluxos territoriais, a partir da migração diária para outras regiões via trem. Este movimento, ao mesmo tempo que ampliou as fronteiras do universo social, também criou pluralidades de referências espaciais, transmitindo valores e tensões entre duas localidades (Carneiro, 2012). Esta disputa entre códigos e valores de um e de outro universo cultural é repassada de pai para filho, estruturando no imaginário social os valores da cidade e os códigos urbanos. De tal sorte que a terra vai perdendo importância na rotina familiar, e o cultivo da roça e o trabalho no barro convertem-se em ocupações de cunho inferior e de caráter vergonhoso ${ }^{8}$.

É nesse sentido que diversas categorias de caráter depreciativo e pejorativo do "mundo rural" são reformuladas e citadas pelas famílias de José Pedro e Antônio Maria para justificar a necessidade da construção da UHE de Jaguara. Expressões como "aqui não tinha nada"; "era um lugar 'pequeninho' demais"; "aqui não valia nada"; "aqui era o fim do mundo"; "porque aqui não era nada"; “aqui era muita pobreza né?”; “não tinham onde trabalhar”, dentre outras, foram frequentes no universo destes que experienciaram a construção da UHE como um fenômeno "positivo". Cumpriria à UHE a criação de novos postos de trabalho para a população; incentivo ao desenvolvimento econômico local; fomento ao desenvolvimento social e econômico familiar; estímulo à educação e

\footnotetext{
${ }^{8}$ A construção subjetiva da vergonha do trabalho e do próprio corpo camponês é uma das marcas dos processos de descamponeização. A propósito das dimensões de violência simbólica deste movimento, ver Bourdieu (2002).
} 
formação de uma classe trabalhadora qualificada; possibilitar a migração de famílias que almejavam deixar a região. Enfim, podemos afirmar que, na percepção de tais famílias, a CEMIG e a UHE não eram apenas as vias efetivas para a modernização do município, mas a garantia de melhorias na qualidade de vida pessoal e familiar. $\mathrm{O}$ depoimento a seguir é exemplar sobre os benefícios que a CEMIG proporcionou aos moradores do município:

Se você for ver, economicamente foi bom, foi muito bom. Mudou! As coisas mudaram,
principalmente no comércio e na economia. Muita gente em Rifaina que hoje eu observo, que
tem uma vida decente em termos econômicos, em termos de patrimônio, deve-se à CEMIG.
Conheço muita gente ali que, sem a CEMIG, não teria ido para frente não [...] Porque foram
trabalhar na CEMIG. A CEMIG sempre pagou muito bem. Hoje eu diria que os aposentados
da CEMIG, eu diria, que não estão tão mal assim, têm casa própria, têm automóveis, uns se
estabeleceram, e assim por diante. A CEMIG trouxe muitos benefícios. [...] Para nossa
família a indenização foi investida em estudos. Porque com esse dinheiro, por exemplo,
formou dois médicos, dentista, formou advogado. Então quer dizer que foi um dinheiro bem
vindo e bem investido (Família Antônio Maria, entrevista realizada dia 14/07/2015. Grifo
dos autores).

Fica claro que as explicações para a adesão e defesa da construção da UHE de Jaguara não se fixam no plano individual, mas se expandem à comunidade local a partir da justificativa de um crescimento de oportunidade de emprego na cidade e transformações no ritmo da economia. "Melhoria de vida", "oportunidade de emprego", "transformação na cidade", "transformação de vida" são alguns relatos que exemplificam esse posicionamento. A propósito deste movimento, convém recorrer às análises de Boltanski e Chiapello (2009) acerca do engajamento individual aos ritmos do capitalismo. Os autores elevam esse engajamento a uma dimensão moral que limita a acumulação ilimitada e, ao mesmo tempo, permite o engajamento subjetivo dos agentes no esforço de gerar valor. A legitimidade da aproximação aos ritmos do capitalismo dá-se pela articulação de duas dimensões essenciais e complementares: a individual e a geral. Assim, para que as transformações capitalistas sejam atraentes, é preciso que a busca ao interesse individual considere critérios do bem estar social e que haja, ao mesmo tempo, motivos pessoais para o engajamento (Boltanski; Chiapello, 2009).

No caso das famílias apresentadas até aqui, as justificações cumprem os princípios expostos pelos autores. Os motivos individuais para empenhar-se na construção da barragem foram expostos em termos da indenização monetária que proporcionou estudo para os integrantes familiares, um novo posto de trabalho sólido e confiável e o crescente distanciamento de um mundo rural considerado arcaico e atrasado. A respeito da última justificação, entendemos que ela não se restringe ao âmbito individual. Ao contrário, estende-se ao coletivo, ao espaço público, especificamente, ao município e aos moradores da cidade que poderiam ser favorecidos por esta transformação. À vista disso, na percepção dos entrevistados, o município e as famílias rifainenses se beneficiaram ao se afastarem de um espaço dito atrasado e subdesenvolvido e se aproximarem do progresso e desenvolvimento que a UHE carrega per si. 
As metamorfoses do espaço rural, bem como as transformações no núcleo familiar, amplamente conhecidas como consequências do processo de construção de barragens (Gonçalves et al, 2001; Reis, 1998; Rocha, 2014; Sigaud, 1986; Viana, 2003; Zhouri, Oliveira, 2007;), tornam-se compreensíveis e justificáveis quando os ganhos não se restringem à esfera privada, mas abarcam os princípios de bem estar social e interesse coletivo. Isso porque o capitalismo não possui em si motivos para fundamentar o engajamento, nem mesmo uma motivação pessoal ou ameaça da fome. Há, portanto, um processo reflexivo e dialético que justifica e legitima o posicionamento dos atingidos. E essa justificação, que incorpora as acepções de razões individuais para o compromisso de acumulação e as atividades lucrativas como um bem comum para a sociedade, permite a estes atingidos questionarem aqueles que se posicionaram contra a construção da barragem e experienciaram este processo negativamente. Foi o que se verificou no relato a seguir: "Ninguém tem que falar nada da usina, da CEMIG, da Mendes Júnior ou da indenização. Nada! Só falar bem! Porque trouxe muitas coisas boas para todos da cidade. Melhorou a vida" (Família José Pedro, entrevista realizada em 17/07/2015). Novamente, a fala dá elementos para compreender o engajamento individual às novas rotinas instauradas pela construção da hidrelétrica - benefício pessoal por meio da indenização -, e apresenta, de modo concomitante, uma justificação geral que serve a um bem comum quando se afirma que "trouxe muitas coisas boas para todos da cidade".

Contudo, a experiência da construção da barragem não foi unívoca. Muitas famílias vivenciaram o processo anúncio - construção - inundação - deslocamento de modo "negativo". E, no cerne das justificativas estão: a violência com que se deu a chegada dos "avaliadores" da CEMIG, a entrada das máquinas e o processo de "negociação" 10 com os moradores; e as perdas, perdas do espaço de trabalho, mecanismo de produção, espaço de memória e lembranças, local de moradia. Então, se para uns os ganhos são justificativas para compreender o episódio como algo positivo, para outros as perdas são essenciais para experienciar como negativo. Nesse ambiente de perdas e ganhos, os conflitos e as tensões instauradas tangenciam a concessionária, mas se aprofundam nas relações interpessoais entre os atingidos.

Nas famílias de Alcides, Berenice e Carlos, o "mundo rural" foi se constituindo como um lugar carregado simbolicamente de sentidos de pertencimento, base identitária e de um ethos camponês. Este "mundo rural" surge, ainda, como território onde as relações de parentesco e vizinhança marcam a paisagem local, reforçando, por conseguinte, o próprio sentimento de

\footnotetext{
${ }^{9}$ Os "avaliadores" eram uma equipe de funcionários da CEMIG que instituía o valor da terra. Este valor se reverteria no montante da indenização paga à família, já que o processo de pagamento se deu pela indenização "territorialpatrimonialista". Segundo os relatos, a equipe dos avaliadores era formada por funcionários da CEMIG (responsáveis pelo anúncio da construção), engenheiros (responsáveis pela medição das terras); às vezes, integrantes do cartório; e ainda advogados.

${ }^{10} \mathrm{O}$ termo negociação deve ser relativizado uma vez que, efetivamente, na visão desses atingidos, não houve negociação. Apenas o anúncio do valor que seria pago pela terra a ser inundada.
} 
pertencimento. A construção da UHE de Jaguara, que reordenou e reconfigurou o território de Rifaina segundo interesses externos e interferências de atores que estavam fora daquela realidade social (Vainer, 2011), atingiu as sociabilidades até então presentes quando, com a formação do lago artificial, desmantelou os mecanismos de produção e inundou o espaço de vida e o universo de experiência de muitas pessoas. Mais uma vez são expostas as diferenças subjetivas entre as famílias atingidas e os contrastes na relação com a terra. Se para as famílias José Pedro e Antônio Maria a terra e o "mundo rural" eram sinônimos de local atrasado, antiquado e conservador, para as famílias de Alcides, Berenice e Carlos eram entendidas como base produtiva, espaço de moradia, local carregado de laços afetivos e lembranças. E isso fica evidente no relato a seguir:

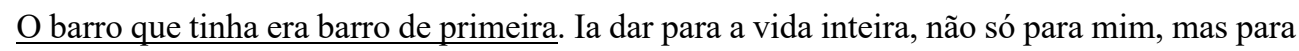
a Rifaina inteira, compreende? Mas inundou! E ficou tudo, tudo debaixo d'água. E, para tirar, tivemos que tirar correndo para não perder tudo, né? Mas ainda assim ficou muita coisa debaixo d'água. Os fornos. Nós tínhamos dois fornos de olaria, um de sessenta metros e outro com trinta. Tirava nove mil tijolos de cada vez. Mas ficou tudo debaixo d'água (Família Alcides, entrevista realizada dia 16/07/2015. Grifo dos autores).

O relato supracitado é sintomático, pois traz em seu cerne variáveis interessantes que justificam a experiência negativa. Primeiro, destacamos a referência à qualidade da terra que fazia barros de "primeira categoria". Barro em abundância que sustentaria economicamente não apenas as famílias produtoras de olarias e cerâmicas, mas supriria a necessidade econômica, social e política da cidade. Isso porque os proprietários de olarias e cerâmicas empregavam mão-de-obra local e ainda proporcionavam terras e moradias para os trabalhadores, autorizando o cultivo para subsistência. Destacamos, aqui, um segundo elemento: o desmantelamento das bases produtivas da região. Em grande medida, a submersão dos mecanismos de produção regional influenciou na trajetória de vida dos atingidos. Por fim, o terceiro elemento a ser destacado é a desinformação, estratégia mobilizada pela CEMIG para facilitar sua inserção na região ${ }^{11}$. Uma vez que não houve o anúncio preciso sobre datas de saída das residências e inundação do local, muitas famílias não tiveram tempo hábil para reestruturem suas produções, nem mesmo salvar o que ainda lhes restavam. Logo, os atingidos saíram, literalmente, correndo do local, retirando seus pertences às pressas, à procura de novos locais para se reinstalarem de forma digna e novos postos de trabalho. À vista disso, na percepção deste grupo, o deslocamento e a reorganização familiar ficou sob total responsabilidade individual, sem auxílio e suporte da concessionária diante das perdas monetárias e perdas não pecuniárias.

A instalação da barragem, e o avanço das lógicas inerentes aos grandes projetos hídricos mudam o ritmo do mundo caipira por meio da apropriação de recursos naturais, usurpação das bases

\footnotetext{
${ }^{11}$ Notadamente, a mobilização de estratégias para facilitar a inserção e instalação de grandes empreendimentos hídricos em um território não é uma particularidade da concessionária CEMIG. Importantes estratégias são mobilizadas pelo setor elétrico a fim de dificultar os movimentos de resistência e criar um sentimento de incerteza e imprecisão. A este respeito, ver Vainer e Araújo (1990).
} 
produtivas e dos mecanismos de produção e, consequentemente, a retirada e deslocamento compulsório das famílias. Contudo, a sequência dos acontecimentos não atinge apenas um mundo externo, mas transforma o ritmo interno dos indivíduos e lesa sua subjetividade e identidade.

Quando as terras inundaram, me senti abalado, senti abalado e pensei: agora eu estou perdido! Agora estou perdido! [...] Virgem! Minha vida mudou completamente, né? Eu tinha uma vida boa, mudou para uma vida ruim. Mas mudança, isso tem em todo mundo, né? Veja a mudança da idade. Eu era moço, né? Eu era moço, mas passou. Mas a mudança da CEMIG foi diferente. A CEMIG veio que veio; veio e "bodegou" nós tudo (Família Alcides, entrevista realizada dia 16/07/0215. Grifo dos autores).

Nessa fala, a afirmação "me senti abalado, senti abalado" é representativa, pois evidencia os impactos internos da instalação de uma hidrelétrica no território. Na mesma direção, as lembranças da família de Carlos expõem a importância da terra na vida e o impacto da perda da terra que firmava um componente da ordem social camponesa (Bourdieu, 1979).

Você vê, eu cortava quatro mil tijolos, dentro de quatro horas e pouco. Não só eu, era muita gente. Eu ainda pescava, pegava quilos e quilos nesse rio [...] Aí a usina chegou, inundou e acabou com tudo. Agora hoje eu fico pensando: está tudo perdido. Eu tinha uma casa boa. Fico pensando, tinha que ter condição, tinha que ter ajuda, mas nada disso aconteceu (Família Carlos, entrevista realizada dia 18/07/2015. Grifo dos autores).

E a família de Berenice complementa:

Ai menina, para te falar a verdade, eu acho que lá era melhor, viu? Antes você tinha tudo.
Você plantava, tudo era grande. Plantava uma mandioca, plantava uma batata, manga,
banana. Você tinha fartura de tudo. Tinha até um chiqueiro para engordar porco. Até se
acostumar aqui foi difícil. Eu comprei aqui sem eu ver. Aí o vendedor foi em casa junto com
o Zito [amigo], aí eu falei “Zito, o terreno é grande? Dá para ir daqui até a mangueira?” Tinha
uma mangueira no meu quintal. Aí ele falou que ia quase, mas não até lá. Porque a gente
sempre gostou de mexer com plantação. Aí comprei sem ver [...] Mas no começo foi difícil
porque era nascida de lá, e ainda tinha tudo. Chega aqui tinha que comprar tudo, até verdura
para sobreviver. Aqui não dá para plantar nada (Família Berenice, entrevista realizada dia
25/11/2015).

Como citado anteriormente, os atingidos relatam acerca da falta de clareza sobre o período de inundação do local e a ausência de orientação da concessionária após o pagamento das indenizações pela residência submersa. Na prática, a CEMIG estipulou um período de noventa dias para que a área fosse desapropriada para a efetiva inauguração da barragem. Isso implicou, concretamente, a abrupta saída das famílias do local, sem um planejamento prévio para a reorganização familiar, econômica e social. Ademais, acarretou a inundação dos instrumentos produtivos dos trabalhadores rurais e seus artefatos produtivos. Fornos, tijolos, telhas, sacas de arroz, entre outros, ficaram submersos pelo fato de os moradores não terem tempo hábil para retirá-los do local, ou mesmo migrar a produção para outro ambiente.

Com relação à ausência de orientação da concessionária após o pagamento das indenizações pela residência submersa, exposto pela família de Carlos como "falta de condição ou falta de ajuda", 
é possível afirmar que, de fato, o pagamento integral da indenização não significou a elaboração de transações monetárias proveitosas e seguras. A inaptidão de manejar um montante elevado de dinheiro contribuiu para acelerar o fim da indenização e agilizar a procura de novos locais para venderem a mão de obra. Isso porque a ação econômica empenhada pelo camponês, segundo Bourdieu (1979), não é estabelecida pelo cálculo racional-econômico estrito da consciência temporal capitalista. A rigor, esta ação econômica tem como fundamento não a abstração do futuro (própria do cálculo capitalista), mas sim experiência acumulada e suportada pela tradição. No processo gradual de adaptação a uma racionalidade econômica capitalista, ficam evidentes as dificuldades do planejamento da poupança capitalista na organização da família camponesa. Com efeito, a dificuldade em planejar e mobilizar grandes quantidades financeiras foi observada em algumas famílias atingidas pela construção da UHE de Jaguara. Segundo os relatos, muitas famílias não conseguiram administrar a indenização monetária e terminaram por comprometer rapidamente os recursos, seja empenhandoos no consumo pouco criterioso, seja acumulando perdas decorrentes das transformações políticas nacionais que registraram diferentes níveis de desvalorização monetária, como podemos observar nos casos a seguir.

\begin{abstract}
Meus irmãos não compraram nada não. Um era até de menor e minha mãe teve que assinar para receber. Casou, foi comprar móveis, fazer festa, acabou com o dinheiro. Teve outro também, Samuel, aí ele comprou passagem para ele e um amigo dele, foram passear na Aparecida do Norte, porque ele queria ir muito, foi para lá e gastou tudo. Veio sem nada. Aí o outro, nem sei o que ele fez. Mas ele estava em Goiânia, veio para cá, pegou esse dinheiro e gastou. Quem comprou mesmo alguma coisa, foi só eu. Dos meus irmãos foi só eu (Família Berenice, entrevista realizada dia 25/11/2015).
\end{abstract}

O dinheiro da indenização sumiu! O pai colocou todo o dinheiro na Caixa, na Caixa Estadual, e com a desvalorização toda, o dinheiro se foi. Tinha também um dinheiro guardado na gaveta, que também se foi. Então, quem comprou alguma coisa, teve algo depois. Meu pai não. Aí o que ele fez!? Como era novo e trabalhava na água ainda, tirando areia nos lugares que sobrou, começou a comercializar areia, sabe? Esse terreno, essa casa aqui, não tem nada a ver com o dinheiro da indenização. Aqui foi no braço mesmo. Ele perdeu praticamente tudo. Por que? Por falta de orientação e pelo tempo mesmo que muitos perdiam [...] Eu era novo na época, não tinha entendimento nenhum, e achava que ele tinha feito bom negócio. Mas não fez não (Família Alcides, entrevista realizada dia 16/07/2015. Grifo dos autores).

As experiências das famílias Alcides, Berenice e Carlos após a construção da UHE, dimensionada e relacionada com a importância da terra (e da água) para cada família, foi significada de modo negativo e revelada nas entrevistas como perdas de diversas ordens. Uma dessas perdas dáse com inundação da terra entendida como base produtiva. Perder o local fundamental de produção dos alimentos necessários para manter o mínimo vital para a sobrevivência familiar deixa-os, em geral, "perdidos”. Há ainda a perda da terra como espaço de moradia que, devido ao contexto histórico da construção da UHE de Jaguara, não esteve em discussão reassentar as famílias atingidas em áreas próximas ou mesmo em reassentamentos rurais coletivos. Ou melhor, não houve reassentamento nem 
mesmo qualquer ajuda por parte da CEMIG; apenas o pagamento de uma indenização monetária previamente estabelecida. Juntamente, houve a perda da terra enquanto perda dos referenciais identitários, evidenciado quando a família de Berenice afirma ter sido difícil se adaptar ao novo local de moradia já que nasceu e cresceu nas terras que foram alagadas. De modo contrário, para as famílias de José Pedro e Antônio Maria, a terra não era reconhecida como provedora de vida ou elemento de ligação entre o indivíduo e o ambiente externo, mas foi concebida como caminho para possíveis rendimentos financeiros e melhoria de vida a partir da indenização monetária quando anunciada a construção da UHE de Jaguara. A desvalorização da terra como espaço de moradia e como base produtiva estimulou o distanciamento das famílias dos ritmos e sociabilidades do "mundo rural", a começar pela reorganização do trabalho no âmbito familiar que denotou como uma atividade em si e para fins econômicos. A confluência destes elementos justifica a experiência da inundação e deslocamento compulsório como algo positivo.

\section{JOGOS OCULTOS ENTRE NEGOCIAÇÃO E INDENIZAÇÃO}

A análise dos relatos orais das famílias revela diversas estratégias dos atingidos no período de construção da barragem, seja para superar as amarras ditatoriais que interditavam as negociações e mudanças nos valores das indenizações, seja para oportunizar ganhos em um contexto de transformação espacial. Eram múltiplas estratégias que se estruturavam com base em mecanismos cotidianos e corriqueiros, recursos silenciosos e pequenas estratégias de um grupo que não podia travar conflitos diretos com o governo.

Para as famílias que experienciaram o episódio negativamente, a permanência no território, tendo em vista a reprodução simbólica, e a inventividade humana para superar os critérios preestabelecidos de pagamento da indenização aspirando à reprodução material foram armas comuns. Em oposição a este grupo, vemos o afastamento do território por meio da migração familiar, bem como a aproximação aos diretores e funcionários de alto escalão das empreiteiras locais, a fim de se beneficiar do contexto histórico. Apesar das estratégias divergentes e contraditórias, todas as famílias tiveram como base de ação condutas próximas àquelas relacionadas como "resistência cotidiana" (Scott, 2002). Com base nesta noção, é possível compreender as pequenas lutas e conflitos que se desdobram diariamente, por homens e mulheres, no sentido de amenizar as amarras da dominação e construir novos arranjos estruturais menos repressivos e menos desfavoráveis à reprodução da vida.

A permanência no território até a data limite da formação do reservatório representou uma tentativa cautelosa das famílias em dar continuidade aos elementos subjetivos da racionalidade camponesa, como a valorização da proximidade aos recursos naturais e o afeto à terra, mas também um ato desesperado pela perda evidente de um espaço inscrito na memória individual e coletiva. 
Houve o esforço de algumas famílias em não ceder às pressões iniciais da CEMIG para abandonar a área de inundação, postura política que levou a concessionária a anunciar a última data possível para permanecerem no local. Somente o anúncio da data limite para a saída das casas e o risco iminente da inundação da área foram motivos plausíveis para que as famílias se afastassem de um espaço que, além de proporcionar os recursos para sobrevivência familiar, carregava dimensões subjetivas que fortalecia o sentimento de pertencimento àquele local.

Tinha gente que não aceitava, que revoltou. Tinha gente que falava: “vou sair daqui morto!". Mas era bobagem. A água iria chegar mesmo, tinha que sair, né? Ficou casa dentro d'água (Família Carlos, entrevista realizada dia 18/07/2015).

Apesar do termo revolta, que desperta um imaginário de confronto direto com grande coordenação, a permanência na área inundada é vista como uma ação política que evitou qualquer confronto aberto com as autoridades. Cientes das desvantagens estruturais e das diversas frentes e possibilidades de repressão, homens e mulheres resistiram silenciosamente segundo interesses pessoais.

A inventividade dos atingidos consiste em outra forma direta, sutil e disfarçada de resistência. Com efeito, recorrer a esta estratégia significou burlar as diretrizes de pagamento de indenização que estavam previamente estabelecidas. De acordo com os relatos empíricos, a CEMIG nivelava todos os moradores das residências com base em um fundamento: ter ou não a propriedade legal do imóvel. Assim, a concessionária, além de excluir dos critérios de indenização a meeiros, posseiros e outros modos possíveis de relação com a terra, apagava também as riquezas e farturas de uma região de solo fértil ao excluir dos critérios de indenização o tamanho do terreno e a capacidade produtiva da terra, características que poderiam ser parâmetros para minimizar as perdas monetárias de proprietários. Destarte, os obstáculos ao conflito aberto, o silenciamento forçado no processo de "negociação", e a impossibilidade de minimizar as perdas monetárias criaram nos atingidos um "espírito de criatividade" para burlar os rígidos critérios da CEMIG. Então, pelas casas e fazendas circularam boatos ensinando aos moradores como ultrapassar as barreiras de dominação da concessionária, superar o que, até então, era insuperável. Por meio de reparações mínimas e rápidas melhorias na residência, além da plantação de árvores frutíferas nos terrenos, criou-se nas famílias um sentimento de esperança na possibilidade de reduzir as perdas monetárias da indenização. Sob a segurança do anonimato, os boatos corriam os ouvidos dos moradores da zona rural e do meio urbano, como importante arma dos atingidos para resistir cotidianamente as pressões e para suprir as necessidades materiais de auto-interesse. Isso fica evidente na seguinte fala:

Mas agora eu vou te contar a história: quem me falou de plantar as bananas e as mangueiras foi um fulano de tal que era neto de um tal que disse: você planta frutas! Planta frutas, não falou bananeiras não, falou planta frutas que eles pagam a mais um pouco. E aí eu plantei mil pés de bananeiras e eles pagaram melhor um pouco [...] Eu plantei arroz também. Se bem 
que arroz eu plantava todo o ano, né? Aí ficou banana e arroz. No meio do arroz eu plantei as bananas (Família Alcides, entrevista realizada dia 16/07/2015. Grifo dos autores).

Se um grupo de moradores optou por permanecer no território até a data limite, afirmando um posicionamento político de ser contra a construção da barragem e o deslocamento, outro grupo optou, estrategicamente, por sair do território logo que a indenização foi paga. Isso porque apenas o desejo de sair de um local caracterizado como "atrasado" e "arcaico" não viabilizava a migração, era preciso boas condições monetárias para que o deslocamento se efetivasse. Assim, o anúncio da edificação da barragem e a declaração dos valores pagos à família oportunizaram a realização de um sonho, qual seja, a saída daquele local.

Por fim, a última estratégia a ser elencada consiste na aproximação aos funcionários das concessionárias, com o intuito de facilitar a entrada nas grandes empresas que chegariam na região. Essa estratégia foi mobilizada por famílias que não conseguiram efetuar a migração para outra cidade após o recebimento da indenização, ou mesmo por homens que, não conseguindo entrar na CEMIG por meio do processo seletivo municipal, recorreram à camaradagem e ao convívio entre amigos para conquistar um cargo dentro da empresa. De forma geral, o intuito dessa aproximação estava para além de conseguir se distanciar de um território que, na percepção destas famílias, era desvalorizado, mas ter a oportunidade por novos postos de trabalho em um local que passava por um intenso processo de desmantelamento das bases produtiva e desestruturação da mão de obra familiar. Então, se algumas famílias faziam "corpo mole" e mostravam-se desinteressadas nas pessoas e no novo ritmo de vida, outras tentavam se enquadrar aos novos padrões, mostravam-se interessadas em aprender o arquétipo citadino em busca de uma ocupação que assegurasse, mesmo que temporariamente, níveis de remuneração e garantias trabalhistas superiores às prevalecentes.

Ela [mãe] foi trabalhar na usina. Ela nunca tinha trabalhado. Só em casa mesmo. Meus pais tinham se separado. Ele [pai] foi embora e deixou minha mãe e todos os filhos para trás. Sem nada! Aí chegou à usina. E a gente estava em uma "merda danada"! Nossa Senhora! Aqui não tinha o que fazer, não tinha nada. E eu nunca trabalhei! A nossa sorte foi essa usina (Família José Pedro, entrevista realizada dia 17/07/2015).

Isto posto, a abertura de novos polos de emprego na cidade foi, para os homens, uma importante estratégia para a mobilidade social e, para algumas mulheres, a oportunidade para elaborar estratégias para sair da condição social no espaço rural, ou seja, conjuntura favorável para a ruptura da dominação de gênero que limitava o espaço da mulher a dimensões físicas e simbólicas específicas. 


\section{CONSIDERAÇÕES FINAIS}

O objetivo deste artigo foi analisar as experiências divergentes e controversas dos atingidos da UHE de Jaguara a partir da técnica de história oral. Por este ângulo, observamos algumas motivações e justificações que balizaram as explicações dadas. Ficou evidente que a experiência e o resultado do deslocamento compulsório, após a instalação da hidrelétrica, foram, para uns, significados de maneira positiva, enquanto, para outros, de maneira negativa. Ou seja, nesse campo de disputa que é o território em transformação pelo empreendimento, as percepções e as experiências dos nomeados atingidos não são unívocas, mas divergentes, opostas, e, algumas vezes, conflitivas.

Resumidamente, se, para alguns, "ter que sair" significou oportunidade de melhorar e mudar de vida, para outros significou a perda do espaço de produção, espaço de moradia e espaço de referenciais identitários. Neste caso, os entrevistados informaram que ficaram desnorteados e desorientados diante da construção da UHE e inundação das terras, e manifestaram o sofrimento e a dor da perda da terra ao longo das falas. Além disso, a submersão da terra significou a perda do espaço de produção, acarretando na migração à procura de novos espaços de trabalho ou no reordenamento produtivo.

Não obstante, aqueles que experienciaram positivamente a construção da barragem não individualizam as justificativas. Ao contrário, estendem ao coletivo e ao espaço público, ampliam as justificativas para o município e outras famílias, salientado que todos foram beneficiados das transformações que a UHE carrega per si. Então, se os motivos individuais foram expostos por meio da indenização monetária que proporcionou estudos e a possibilidade de melhor posto de trabalho, no âmbito geral, foi a possibilidade de afastar famílias do município rural por meio do deslocamento compulsório, distanciando de um mundo rural considerado atrasado, arcaico e ultrapassado.

Em termos do reordenamento fundiário, cumpre ressaltar que o turismo rural passou a ocupar um papel central na economia da cidade e no sustento familiar. Cessaram-se todas as produções agrícolas da região com a formação do lago artificial, e, a posteriori, houve uma crescente especulação imobiliária de casas de veraneio e ranchos que margeiam as águas. Contudo, esse novo mercado não beneficia a todos os moradores, nem mesmo todas as famílias apresentadas neste trabalho. A rigor, há conflitos e tensões com aqueles que vêm "de fora" a fim de consumir um ambiente valorizado por suas características "naturais".

Através deste estudo de caso, também foi possível investigar as diferentes estratégias de atuação deste grupo social junto à concessionária propositora da obra no período de "negociação" e recebimento da indenização. Neste sentido, as famílias utilizaram de resistências silenciosas para minimizar perdas e oportunizar ganhos em um período em que o confronto aberto e direto era inviabilizado pela possibilidade de repressão intensa. 
Por fim, a conjuntura sócio-política aqui interpretada, em confluência com os visíveis posicionamentos divergentes, trazem para o centro da reflexão a categoria "atingido", conceito em constante disputa, que varia no tempo e no espaço consoante ao contexto político e cultural da época. Há entre os atingidos múltiplas identidades que transitam entre o "ser atingido" e o "sentir-se atingido". Assim, perceber a construção de uma identidade de atingido como resultado das experiências historicamente vivenciadas pelos agentes em análise, nos possibilita sair de um espectro mais amplo - o "ser atingido" -, e aprofundar nos valores e percepções divergentes de cada família que coloca em xeque um "sentir-se atingido", ou seja, um sentimento forjado pela consciência e reconhecimento de danos e perdas, e a percepção de dever lutar pelos próprios direitos e contra a construção da barragem. Seguramente, considerar as famílias como agentes históricos reais amputa qualquer tentativa de pressupor uma lei nas reações dos indivíduos. Isso explica que, apesar de algumas famílias serem enquadradas como atingidas por terem as terras inundadas, o sentimento pessoal e a experiência não são de perdas e danos, mas ganhos e lucros, por compreenderem melhorias em âmbito pessoal e regional.

\section{REFERÊNCIAS}

AGUIAR, V. V. P. O trabalho das mulheres nos espaços rurais: algumas reflexões. Raízes. Campina Grande, v. 37, n. 02, 2017, p. $134 \quad-\quad 149$. Disponível em $<$ http://raizes.revistas.ufcg.edu.br/index.php/raizes/article/view/71>. Acessado em: 30 de Maio de 2020.

BOLTANSKI, L; CHIAPELLO, E. O novo espírito do capitalismo e o papel da crítica. In: . $O$ novo espírito do capitalismo. São Paulo: WMF Martins Fontes, 2009.

BOURDIEU, P. O desencantamento do mundo: Estrututuras econômicas e estruturas temporais. São Paulo: Perspectiva, 1979.

BOURDIEU, P. Le bal des célibataires: crise de la société paysanne en Béarn. Paris: Éditions du Seuil, 2002

BRANDEMBURG, A. Do rural tradicional ao rural socioambiental. Ambiente \& Sociedade, Campinas, v 13, n.2, p. 417-428, jul/dez. 2010. Disponível em: < https://www.scielo.br/pdf/asoc/v13n2/v13n2a13.pdf>. Acessado em: 05 de Fevereiro de 2020.

CANDIDO, A. Os parceiros do rio bonito: estudo sobre o caipira paulista e a transformação dos seus meios de vida. $11^{\mathrm{a}}$ ed. Rio de Janeiro: Ouro sobre Azul. 2010.

CARDOSO, J. P. Trajetórias de vida e de classe: um estudo sobre rearranjos territoriais e identitários na implantação da usina hidrelétrica de Jaguara. São Carlos, 2016, 196p. Dissertação (Mestrado em Sociologia) - Centro de Educação e Ciências Humanas, Universidade Federal de São Carlos, 2016. Disponível em: $<$ https://repositorio.ufscar.br/handle/ufscar/7999>. Acessado em: 10 de Março de 2020.

CARNEIRO, M. J. Do rural como categoria de pensamento e como categoria analítica. In: Ruralidades Contemporâneas: modos de viver e pensar o rural na sociedade brasileira. Rio de Janeiro: Mauad X: FAPERJ, 2012. p. 23-50. 
GASKELL, G. Entrevistas individuais e grupais. In: BAUER, M. W.; GASKELL, G. (org.). Pesquisa qualitativa com texto, imagem e som. 2 ed. Petrópolis: Vozes, 2003.

GONÇALVES, J. C; VALENCIO, N. F. L. S; MARTINS, R. C.; LEME, A. A. Análise das Alterações de Comportamento do Mercado de Terras Rural Provocadas pela Implantação de Megaprojetos Hídricos. In. VALENCIO, N. F. L.S; MARTINS, R. C; LEME, A. A. (Orgs.) Uso e Gestão dos Recursos Hidricos no Brasil. São Carlos: RiMa, 2001, p. 149-164.

HALBWACHS, M. A memória coletiva. São Paulo: Centauro, 2006.

HENRIQUES, M. S. Pelo sim, pelo não: a construção de barragens e a opinião pública. In. LOCATELLI, C. (Org). Barragens imaginárias: a construção de hidrelétricas pela comunicação. Florianópolis: Insular, 2015, p. $37-56$.

HIRATA, H; GUIMARÃES, N. A. Cuidado e cuidadoras: as várias faces do trabalho do care. São Paulo: Atlas, 2012.

LOCATELLI, C. Sobre comunicação e barragens In. LOCATELLI, C. (Org). Barragens imaginárias: a construção de hidrelétricas pela comunicação. Florianópolis: Insular, 2015, p. 13 36.

MARTINS, R. C; MADUREIRA, G. A. Do "buraco" ao atrativo turístico: uma sociologia da ressignificação do rural. Revista de Economia e Sociologia Rural, vol.57, n.2, p.326-338, 2019. Disponível em: $\quad<$ https://www.scielo.br/scielo.php?pid=S010320032019000200326\&script $=$ sci_arttext $>$. Acessado em: 22 de Maio de 2020.

MENEZES, M. A. Economia moral em James Scott e as perspectivas de seus críticos. Raízes. Campina Grande, v. 39, n. 2, jul/dez. 2019. Disponível em: < http://raizes.revistas.ufcg.edu.br/index.php/raizes/article/view/106>. Acessado em 30 de Maio de 2020.

PAULILO, M. I. S. O peso do trabalho leve. Ciência Hoje, Rio de Janeiro: SBPC, v. 5, n. 28, p. 6470, 1987. Disponível em < https://nafa.paginas.ufsc.br/files/2010/09/OPesodoTrabalhoLeve.pdf $>$. Acessado em: 15 de Junho de 2015.

QUEIROZ, M. I. P. Relatos Orais: do “indizível” ao “dizível. In: SIMSON, O.M.V. Experimentos com Histórias de Vida (Itália-Brasil). São Paulo: vértice, 1988. p. 14-43.

REIS, M. J. Espaços vividos, migração compulsória, identidade: os camponeses do Alto Uruguai e a hidrelétrica de Itá. Campinas, 1998. 253p. Tese (Doutorado em Ciências Sociais) - Programa de PósGraduação em Ciências Sociais, Universidade Estadual de Campinas, 1998.

ROCHA, H. J. O controle do espaço-tempo nos processos de instalação de hidrelétricas. Tempo Social, Revista de sociologia da USP, v. 26, n. 1. p. 259-280. Jun 2014. Disponível em: < https://www.scielo.br/pdf/ts/v26n1/15.pdf>. Acessado em: 22 de Outubro de 2015.

SILVA, E. M. Das margens do rio São Francisco às marginalidades do Lago de Sobradinho. Raizes. Campina Grande, v. 34, n. 1, p. $49-64,2014$. Disponível em: $<\underline{\text { http://raizes.revistas.ufcg.edu.br/index.php/raizes/article/view/402> }}$. Acessado em: 20 de Fevereiro de 2020.

SCOTT, J. The Moral Economy of the Peasant. Rebellion and subsistence in Southeast Asia. New Haven and London: Yale University Press, 1976.

SCOTT, J. Formas cotidianas de resitência camponesa. Raízes, Campina Grande, v. 21, n. 01, p. 1031, jan.jun. 2002. Disponível em: http://raizes.revistas.ufcg.edu.br/index.php/raizes/article/view/175 $>$. Acessado em 15 de novembro de 2015.

SIGAUD, L. Efeitos sociais de grandes projetos hidrelétricos: as barragens de Sobradinho e Machadinho. Rio de Janeiro: Museu Nacional - UFRJ. 1986. 
STROPASOLAS, V. O valor (do) casamento na agricultura familiar. Estudos feministas, Florianópolis, v. 12, n. 1, p. 253-267, Jan./Abr. 2014. Disponível em: < https://periodicos.ufsc.br/index.php/ref/article/view/S0104-026X2004000100013 >. Acessado em 18 de Janeiro de 2016.

THOMPSON, E. P. A miséria da teoria ou um planetário de erros: uma crítica ao pensamento de Althusser. Rio de Janeiro: Zahar Editores, 1981.

VAINER, C. B. O que é o “Grande Projeto”? Características econômicas, territoriais, políticas e sociais. In: SPM; CEM; CSEM; CETESP; ITESP (Org). Seminário Grandes Obras e Migrações. São Paulo: SPM, 2011, p. 33-45.

VAINER, C. B. Conceito de "atingido": uma revisão do debate. In: ROTHMAN, Franklin Daniel. (Org.). Vidas Alagadas - conflitos socioambientais, licenciamento e barragens. Viçosa: UFV, 2008, p. 39-63.

VAINER, C. B.; ARAÚJO, F. G. B. Implantação de grandes hidrelétricas. Estratégias do Setor Elétrico. Estratégias das populações atingidas. Revista Travessia, ano 2, n 6, p. 18-24, jan./abr. 1990.

VIANA, R. M. Grandes barragens, impactos e reparações: um estudo de caso sobre a barragem de Itá. Rio de Janeiro. 2003. 190f. Dissertação (Mestrado em Planejamento Urbano e Regional) Universidade Federal do Rio de Janeiro, 2003.

ZANFELICE, T; ETCHEBEHERE, M. L; SAAD, A. R. Avaliação preliminar do potencial turístico do Município de Rifaina (SP) e os impactos decorrentes do uso público de seus atrativos paisagísticos.

Geociências, São Paulo, v. 28, n. 2, p. 203-220, 2009. Disponível em: $<$ http://www.ppegeo.igc.usp.br/index.php/GEOSP/article/view/7109>. Acessado em 23 de Abril de 2016.

ZHOURI, A. e OLIVEIRA, R. Desenvolvimento, conflitos sociais e violência no Brasil rural: o caso das usinas hidrelétricas. Ambiente \& Sociedade, Campinas, v. x, n. 2, p. 119-135, jul - dez, 2007. Disponível em: < https://www.scielo.br/pdf/asoc/v10n2/a08v10n2.pdf $>$. Acessado em: 19 de Maio de 2015.

WEBER, M. Economia e Sociedade: fundamentos da sociologia compreensiva. Brasília: Editora Universidade de Brasília, 1991. 